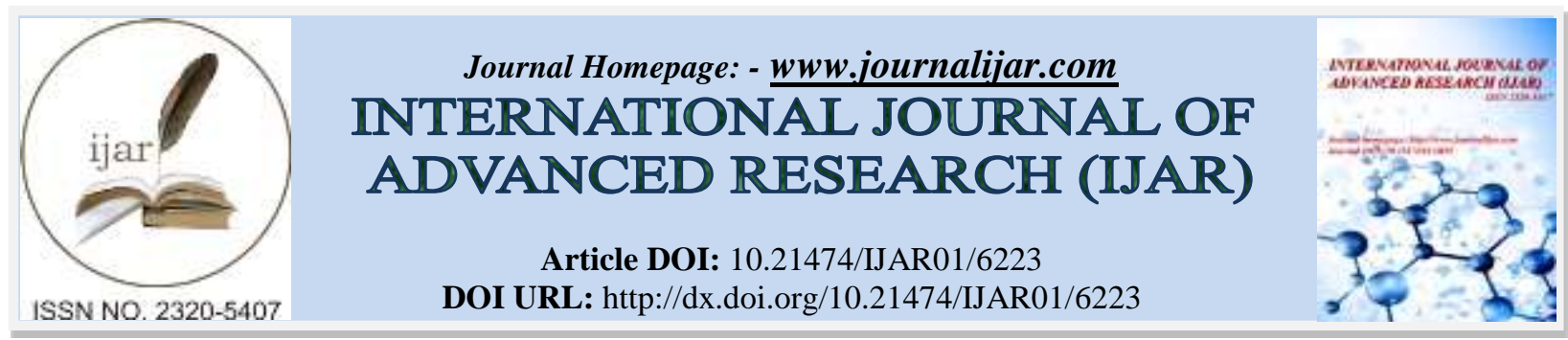

RESEARCH ARTICLE

\title{
ALCHORNEA CORDIFOLIA (SCHUMACH. \& THONN.) MÜLL. ARG: A POTENTIAL PLANT FOR PHYTOREMEDIATION OF MANGANESE POLLUTED SOILS.
}

\author{
"Mokea-Niaty A. ${ }^{1}$, Medza-Mve S. D. ${ }^{1}$, Lepengue A. ${ }^{1}{ }^{1}$, Moupela C. ${ }^{1}$, Ognalaga M. ${ }^{1}$, Mboumba P. ${ }^{1}$, Toussaint \\ A. ${ }^{2}$ and M'BATCHI B. ${ }^{1}$
}

1. Université des Sciences et Technique de Masuku (USTM), Unité de Recherche Agrobiologie Laboratoire de Physiologie et Biotechnologie Végétale, B.P. 901 ; Franceville, Gabon.

2. Univ. Liège-Gembloux Agro-Bio Tech. Unité de Phytotechnie Tropicale et Horticulture. 2, Passage des Déportés, B-5030 Gembloux (Belgique).

\section{Manuscript Info}

........................

Manuscript History

Received: 05 November 2017

Final Accepted: 07 December 2017

Published: January 2018

\section{Key words:-}

phytoremediation, Alchornea cordifolia, manganese, pollution.

\section{Abstract}

Mining in the Moulili area, a stream of the Ogooue mining site, has been affected by the collapse of river banks and pollution due to Manganese. In order to restore this watercourse and stabilize its banks, a strategy could be introduced by involving the use of biological processes such as phytoremediation techniques. Phytoremediation of soil contaminated with heavy metals can be divided into four major groups: phytostabilisation, phytoextraction, phytotransformation or phytofiltration. This strategy can be based on the use of Alchornea cordifolia, a local plant which is tolerant to manganese, therefore, having good capacities for the extraction and accumulation of this trace metallic element.

Copy Right, IJAR, 2018,. All rights reserved.

\section{Introduction:-}

Human activities, including mining, generate much waste that is enriched with metals. Their dispersal in soils is dangerous to the flora, fauna and man, who is found at the end of the food chain (Ghnaya et al., 2006). Due to their persistence, toxicity and increasing environmental grades, metals represent one of the most important environmental pollutants worldwide (Delcarte et al., 2013). In order to rehabilitate polluted soils, physico-chemical methods of treatment are often expensive and generally appropriate for the decontamination of localised areas where acute pollution and land pressure is high. These heavy techniques very often affect the biological activity of soils and degrade their structure, leaving the residues partially or totally sterile. While current technologies for water and soil treatment are available, strong interactions with the organo-mineral matrix makes it difficult to extract or inactivate soil pollutants from available technologies without altering the properties of the environment. Biological pathways for soil decontamination appear to be substitutes or complementary methods that are cheaper, more extensive, and that are more suitable for individual soil's characteristics (Hooda, 2007). Phytoremediation is an alternative method of depollution of contaminated soils, through the use of plants, and has been attracting the interest of many for the last decade. This new technology exploits the potential of plants and their associated microbiota to extract, stabilise or volatilise heavy metals in soils. It is regularly mentioned in the scientific community as a promising solution for the future. This process exploits the different physiological mechanisms of plants that allow them to grow in a contaminated environment. A part of the implementation of a manganese pollution management strategy for mining sites and their environment, being one of the phases of the implementation of a sanitation and rehabilitation program 
by phytoremediation, entails the identification and specific characterisation of the plant material to be used in order to meet the objectives of sustainable management.

Preliminary studies which aimed at screening all the species that can enter into a program of stabilization in Moulili's banks, a stream that flows through the site of Ogooue mining company and heavily polluted by this element in the south east of Gabon, showed that Alchornea cordifolia (Schumach. \& Thonn.) Müll. Arg, a plant from the family of Euphorbiaceae, has good phytoremediation abilities. Due to its strong phytoaccumulating potential of manganese in the leaves (unpublished result) and its powerful root system, this plant presents itself as having potentials for extracting this metal trace element (MTE) from the soil, while also establishing the river banks of the stream. The aim of this study is to better understand the concept of phytoremediation and to have a global view on the potentials of $A$. cordifolia for phytoremediation and the phytostabilisation of the banks of this river

\section{Phytoremediation:-}

Phytoremediation is a set of technologies that uses plants to reduce, degrade or immobilize organic pollutants (natural or synthetic) from soil, water or air as a result of human activities. This technique also allows the treatment of MTE, radionuclide, and organic pollution (Wolverton, 1980). It is one of the innovative methods of soil decontamination increasingly used in complex environments, depending on the nature of the pollutants to be treated. They are biological treatments applied to polluted soils whose use goes back to the mid-1980s, but their generalization only dates from the 1990s. Being fully expanded in North America, phytoremediation was still a dozen years in Africa, particularly in Gabon. It offers a real ecological and financial alternative to traditional depollution techniques, such as excavation, spreading or incineration, for the rehabilitation of quarries and affected areas (Hooda, 2007).

Consequently, it is a very broad concept that covers a range of relatively different technologies, but all based on the use of plants to reduce the ecotoxicological risks associated with soil contamination. The principle of decontamination by phytoremediation relies on the plant's absorption of the contaminant to metabolize or store it, reduce or even prevent its release into other compartments of the environment. Most often, organic compounds (xenobiotic or not) can be degraded and metabolized for the growth of the plant. After, the pollutant is then eliminated. When composed of inorganic compounds (metals, metalloids or radionuclides), they can only be stabilized or extracted because these pollutants are not biodegradable. Phytoremediation is divided into two main categories, phytostabilisation and phytodecontamination, which uses phytoextraction, rhizofiltration and phytomining techniques. There are other alternatives of phytoremediation techniques such as phytodegradation (transformation of pollutants into less toxic substances), rhizodegradation (phytodegradation in the rhizosphere) and phytovolatilisation, which eliminate volatile pollutants. We should focus on phytoremediations (Zhang et al., 2010).

\section{Phytostabilisation:-}

It consists of immobilizing in situ the contaminants of the soil and its waters via the roots of the plants by absorption, adsorption or precipitation in the rhizosphere. This technique is applicable to sites where the bioavailability of metals is reduced and the movements of pollutants estimated. This process makes it possible to separate the heavy metals present in the distance between soil sides corresponding to the root system of the plants and, thus, preventing their migration by wind erosion, runoff or towards groundwater (Leteinturier, 2002). Phytostabilisation would help to correct secondary impacts such as bare soil erosion. This method of phytoremediation makes it possible to limit the transport of particles loaded with pollutants by water and wind. It is based on soil-root-pollutant interactions. The rhizosphere effects correspond to stimulation of microbial growth. Vegetation cover stabilizes soil and pollutants. Changes in the rhizosphere, with root exudates that lead to changes in soil $\mathrm{pH}$, stimulates biological activity, which can contribute to the degradation of organic pollutants and the production of carbon dioxide of intermediate products. It also contribute to the transformation of organic pollutants. The plant prevents the entry of metals by immobilizing them in the rhizosphere or separating them in the root cells, while limiting their transfer to the upper parts of the plant. The concept of phytostabilisation is based on the fact that vegetation cover influences the stability of contaminants in the soil, but also contributes to nutrient enrichment and soil biological activity (Vervaeke et al., 2003). This technique is often considered for revegetation and valorization of sites rendered unusable by contamination (Quigley, 2005). The installation of a vegetation cover reduces the risks to human health and the environment by limiting the dispersion of contaminants to groundwater, the atmosphere, and surrounding ecosystems. This is not a standardised technique and each case must be assessed individually. 


\section{Phytoextraction:-}

Phytoextraction allows the plant to remove pollutants through its roots and transfer them to the aerial parts where they are separated in the leaves. Plants absorb and concentrate in their harvestable parts (leaves, stems) the pollutants contained in the soil. Accumulating and/or accumulative plants are used, which are capable of tolerating and accumulating MTEs. Most often, the plants are harvested, incinerated and the ash is stored or recovered to obtain the accumulated metals (phytomining). This technique is based on the ability of certain plants to capture, transport and accumulate metals in stems and leaves, through compartmentalisation and chelation mechanisms. Some species are even capable of mobilising metals to facilitate their accumulation (Raskin et al., 1997). The ability to accumulate metals depends on the plant species or the ecotypes/varieties of the same species. Each species, or even individual, has established mechanisms of absorption based on the genetic, morphological, physiological and anatomical characteristics of the plant. According to Aricia and Bruno (2013), several views on phytoextraction have developed. The first one focuses on the study of hyper-accumulating plants capable of accumulating up to 100 times more metals than non-accumulating plants. These plants are classified as hyperaccumulative when the biomass contains more than $1 \% \mathrm{Ni}, \mathrm{Zn}$ or $\mathrm{Mn}$ or more than $100 \mathrm{mg} \mathrm{Cd} / \mathrm{kg}$. However, their use remains limited due to low biomass production. The ideal plant for phytoextraction should combine high biomass and pollutant accumulation.

Another point of view is the use of woody species which, due to the high production of biomass, will make it possible to extract a large quantity of pollutants present in the soil. Phytoextraction by biomass production is a slow technique, requiring several years or even decades before meeting the sanitory objectives. It is therefore more appropriate to consider phytoextraction in combination with conventional physico-chemical techniques in order to ensure that the site is cleaned up in reasonable time and at lower cost (Lesage et al., 2005). Phytoextraction exploits the ability of certain accumulative or hyperaccumulative plants to transfer heavy metals from roots to their leaf tissues via transporters, with the aim of extracting pollutants from contaminated soil. Contaminants are stored in plant biomass via lignification and leaf cell vacuoles (Sinha et al., 2013).

\section{Phytotransformation or phytodegradation:-}

Some plants produce enzymes, such as dehalogenase and oxygenase, that catalyses the degradation of absorbed or adsorbed substances; these are transformed into less toxic or non-toxic substances by metabolizing contaminants in plant tissues or by plant-held rhizosphere organisms (Mahmood et al., 2013). The metabolism of pollutants, such as highly volatile chlorinated solvents and other trace elements, can then be volatilized. It is the transformation of elements such as selenium, mercury or arsenic by microorganisms and plants; the microbial methylation of selenium, for example, is very effective in the rhizosphere (Kushwaha et al., 2016). Plants absorb water from the lithosphere containing organic contaminants and other toxic products, turning them into volatile elements, and releasing them into the atmosphere via their leaves. They may also, in some cases, transform organic contaminants into volatile elements before they are transferred (Aydin and Coskun, 2013). The contaminants supported by this phytoremediation technique are generally of the organic type. However, several studies have concluded that inorganic contaminants can also be dispersed in volatile form in the atmosphere by phytovolatilisation. Phytodegradation/phytotransformation can result in a partial or total reduction of the pollutant content (Moogouei et al., 2011). Contaminants are metabolized in plant tissues. The plants produce enzymes, such as dehalogenase and oxygenase, which catalyses these degradations. Phytodegradation is a set of processes that involves the absorption, metabolism and degradation of contaminants in the plant. It can also lead to the degradation of contaminants in soil, sediment, sludge, groundwater or surface water by enzymes produced and released by the plant. It does not depend on the association between microorganisms and the rhizosphere. Phytodegradation-based contaminants include organic compounds such as chlorinated solvents, herbicides and insecticides, and inorganic compounds (Vishnoi and Srivastava, 2007).

\section{Phytofiltration or Rhizofiltration:-}

The rhizosphere is the immediate environment of the roots, and benefits from regular intakes of organic compounds derived from them, called exudates, representing a very wide range of molecules, from glucose to polysaccharides. Used by soil microflora as a source of carbon and energy, these exudates induce a significant increase in the number of microorganisms in the vicinity of the root. These root exudates can influence the behaviour of MTEs by reducing or increasing their availability. This is made possible by the modification of the $\mathrm{pH}$, activation of redox reactions, precipitation and chelation. The cell wall and the plasma membrane can also limit the passage of the metals towards the interior of the cell, based on their exchange capacity (Kidd et al., 2009). 
Root sampling is a function of the concentrations and speciation of metals in the soil solution; movements of metals in the soil to the root surface; the transportation of metals from the root surface to the inside of the root via transporters (proteins); and the translocation of roots to leaves (Zhang et al., 2010). These mechanisms are influenced by the presence of microorganisms present in the rhizosphere, which can increase the root surface of absorption and assist in the extraction of nutrients. Microorganisms can also have negative effects: release of toxic substances and separation of nutrients. The roots possess a cation exchange capacity. Remediation and restoration of groundwater is done by adsorption or absorption of contaminants via plant roots (Yadav, 2010).

Rhizofiltration (also known as phytofiltration) is capable of removing contaminants from plant roots in surface waters, wastewater or extracted groundwater by adsorption or precipitation. It has generally focused on contamination by metals such as titanium, chromium and mercury. However, it can be used for the remediation of areas polluted by organic contaminants and their metabolic by-products, which can be fixed or incorporated into plant components such as lignin (Harms and Langebartels, 1986). This form of phytostabilisation is known as phytolignification (Cunningham et al., 1995).

The microorganisms of the rhizosphere also play an important role in the mobilization or immobilization of the elements in the soil. They influence the entry of nutrients and other metals into the plant by establishing symbiotic associations with roots (Krznaric et al., 2009). Once installed, symbiosis can protect the plant from toxicity of metals by increasing their tolerance (Joner et al., 2006). The effect of mycorrhizae on the tolerance of the plant is however variable, probably because it must be specific to both the metal and the plant. Fungi from contaminated media would be able to restrict the absorption of zinc, for example (Cook and Hesterberg, 2013). However, some adapted ectomycorrhizae plays an important role in the accumulation of certain metals. Endomycorrhizae improves tolerance in the plant, on the one hand by modulating the expression of certain enzymes involved in photosynthesis and carbon fixation, and on the other hand by promoting the action of antioxidative defences such as sulfur compounds and peroxidases (Gamalero et al., 2009).

\section{Manganese and Biodegradability:- \\ Manganese in Soil:-}

Manganese and its derivatives are strongly retained in soils either by cation exchange reactions (manganese ions reacts with chemical compounds present on the soil surface to form oxides, hydroxides and oxyhydroxides of manganese) or by reactions of ligand exchanges (the manganese is then adsorbed on other oxides, hydroxides or oxyhydroxides). When the soil water become saturated as oxides, hydroxides and oxyhydroxides of manganese, they precipitate, causing a new phase which will act as a new surface on which other substances can be adsorbed (Habeck, 2011). In soils, there is a balance between the divalent and trivalent forms of manganese: divalent manganese is transformed by biological oxidation into a trivalent form, which in itself is biologically reduced to divalent manganese (IUCLID, 2000). A dynamic equilibrium can be established between the valences of the manganese. In low-aerated soil, biological reduction may occur for all $\mathrm{pH}$ values. In the case of usual aeration, the reduction by organic matter in acid soils is important and bacterial oxidation is practically non-existent: the divalent form of manganese is dominant in acidic soils $(\mathrm{pH}<5.5)$. Conversely, in basic soil $(\mathrm{pH}>7)$, bacterial oxidation is rapid and reduction is by slow organic matter: the trivalent form dominates (Smith and Paterson, 1995). When the divalent form of manganese is dominant, it may compete with other cations in exchange reactions, or it may be strongly involved in complexation reactions with the organic matters in the soils or the roots of higher plants (Gheju and Stelescu, 2013; Kabata Pendias, 2010).

The divalent form of manganese in clay or silt suspension is oxidized by microorganisms, resulting in the precipitation of manganese minerals. The bioaccumulation of manganese depends on several factors, including the species in which it occurs. Plants absorb manganese mainly in its divalent form. As a result, manganese is more bioavailable in acidic soils than in alkaline soils. On the other hand, the absorption of manganese by plants is favoured by the presence of microorganisms (Adriano, 1986; Adriano et al., 2004).

\section{Manganese Plant Tolerance Systems:-}

Plants have different physiological mechanisms that allow them to grow in an environment contaminated by MTE. According to Aricia and Bruno (2013), a series of gene families are involved in the separation and compartmentalization of metals within the cell. Plant tolerance to manganese pollution is based on two mechanisms: 
The first is constitutive with the binding of $\mathrm{Mn}$ to cellular components. There are enzymes detoxification mechanisms involving superoxide dismutase (SOD). SODs are metallo-enzymes found in plants. There are three types of SOD containing prosthetic groups that contain iron (FeSOD), manganese (MnSOD) or copper and zinc (CuZnSOD). All of them catalyses the dismutation of two superoxide anions to dioxygen and hydrogen peroxide. MnSOD are located mainly in the matrix of mitochondria and glyoxysomes or membrane-bound peroxisomes of foliar cells (Arora et al., 2002; Rodríguez-Serrano et al., 2007). When ions or complexes of heavy metals are stored in organelles, especially vaccines, they are then eliminated by falling leaves, and this is referred to as exclusion (Ernst et al., 1992). The accumulation of manganese and other heavy metals in plant tissues is affected by soil and atmospheric characteristics and plant absorption capacity (Bin et al., 2001).

The second mechanism of plant tolerance to pollution is inducible with chelation to phytochelatins (PCs). PCs are synthesised from glutathione (GSH) and are cysteine-rich polypeptides. These macromolecules possess thiol groups capable of chelating metals. This process leads to the formation of phytochelatins, which are crucial for the chelation of $\mathrm{Mn}^{2+}$ ions. Phytochelatins have a high affinity for $\mathrm{Mn}^{2+}$ ions when the concentration of the latter can cause cellular damage. Chelation of PCs with $\mathrm{Mn}^{2+}$ ions forms $\mathrm{Mn} / \mathrm{binder}-\mathrm{Pcs}$ complexes. These complexes are transported and stored in the vacuole, thus protecting the cytoplasmic enzymes (Rauser, 1990). GSH is also used by GSH S-transferase in the detoxification of organic compounds (Moons, 2005). This accumulation strategy involves physiological processes that require cells to maintain $\mathrm{Mn}$ and heavy metal intracellular ions, but in non-toxic form (Cobbett, 2000).

\section{Alchornea cordifolia:-}

The ideal plant for the phytoremediation of soil contaminated with MTEs must be metal-tolerant specie capable of growing rapidly on nutrient-poor soil with a deep root system (Punshon, 1996). The possibility of upgrading contaminated biomass produced in any economic process is also an important criterion (Pulford and Watson, 2003). Alchornea cordifolia (Schumach. \& Thonn.) Müll. Arg seems to combine these assets and presents potentials for the rehabilitation of polluted soils. These advantages are based on its physio-morphological characteristics, in particular, its highly developed root system which can control the spread of pollution, the dispersion of MTEs and their transfer to the environment. According to a preliminary study (unpublished), its roots absorb large amounts of Mn at depths of more than three meters and have a rapid growth even on marginal soils. A. cordifolia also develops an important biomass capable of storing large quantities of pollutants. Its annual biomass production is two to three tons per hectare without amendments (Mavar-Manga et al., 2007). Similarly, its distribution extends throughout the subSaharan zone, from swampy areas to degraded environments, and by-products of sizes and maintenance could be upgraded in bioenergy sectors.

\section{Botanical:-}

A. cordifolia is a small evergreen tree or evergreen shrub sometimes climbing with a size varying between 5 and $10 \mathrm{~m}$ tall (Figure 1). It belongs to the family of Euphorbiaceae and is known as the Djeman tree in French in West Africa, and "Christmas bush" or "dovewood" in the English-speaking areas (Osumah, 2012). Considered as a creeping plant because of its long intermingled branches, the majority of scientists agree that it is a shrub. Its erect branches, with flared and falling ports depending on location, start from the base to become horizontal depending on where the plant grows. Its bark is smooth, gray with a reddish brown edge. Its branches are pubescent to glabrousness, being gray to brown (Mavar-Manga et al., 2007; Friis and Harris, 2013). The leaves are alternate, simple with sometimes entire edges, but mostly toothed or fluted with triangular stipules about 1.5 millimetres long. They are 5 to $25 \mathrm{~cm}$ long and 3 to $15 \mathrm{~cm}$ wide. They are round at the base and narrow at the tip and have a limb that is oval to elliptical-oval (White and Abernetty, 1996). As in most Euphorbiaceae, the base of its leaves present on their lower surface 3 to 5 ribs with 5 to 4 glandular spots. Leaves that quickly become deciduous have a petiole whose length varies from 3 and 15 centimetres long (Friis and Harris, 2013).

Alchornea cordifolia is a dioecious plant with unisexual flowers. The male inflorescences consist of flowers with two sepals in sections and eight stamens. The fibres are welded and form a basal plate. These male inflorescences are in axillary panicle from 8 to $45 \mathrm{~cm}$ long with disseminated hairs and tiny bracts. The fruits are capsules with two or three boxes more or less flattened about $1 \mathrm{~cm}$ in diameter. These capsules formed from hairy pubescent shells contain red seeds at maturity. Fruits are divided into two sections that grow in clusters of plus or minus 30 fruits. The flesh is compact and greenish with a texture reminiscent of a still green peach. The seeds are ovoid-ellipsoid, about $6 \mathrm{~mm}$ long, smooth and bright red (Arbonnier, 2002). 


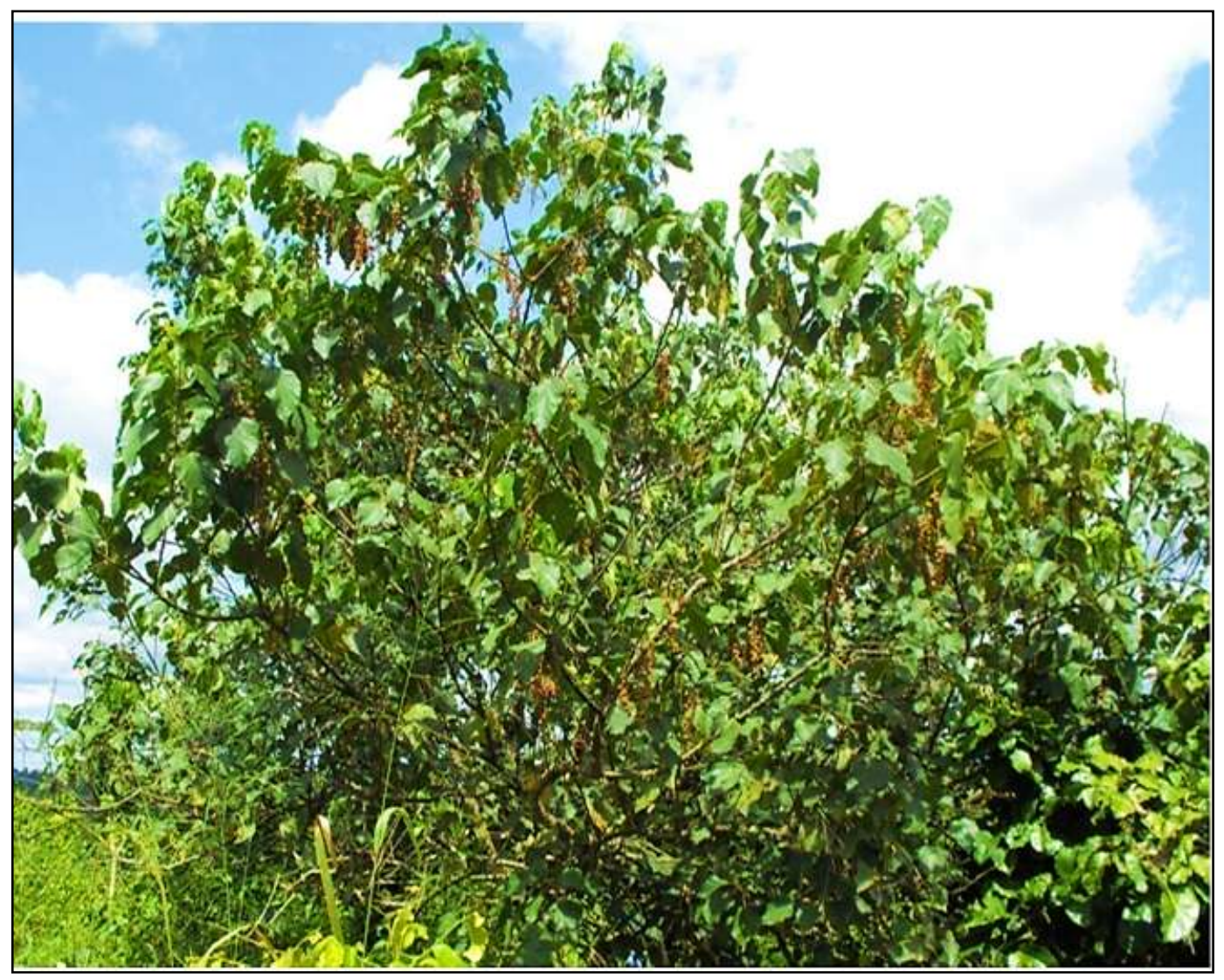

Figure 1:- Plant of Alchornea cordifolia (Osumah, 2012)

\section{Geographical Distribution, Ecology and Propagation of Alchornea cordifolia:-}

Alchornea cordifolia is present from Senegal to Kenya and Tanzania and southwards throughout Central Africa to Angola. It is widespread across Africa and particularly in tropical Africa. It is a pantropical species belonging to the plains of West Africa and the Quaternary forests (Miller and Gosling, 2014). It is found in secondary forests and riparian areas, mainly in marshy areas, but sometimes also in drier places, from sea level up to $1500 \mathrm{~m}$ altitude. It often forms thickets in areas disturbed but spared by fires. This plant adapts to acidic soils in secondary forests (Mavar-Manga et al., 2007), lowland scrub and degraded habitats such as the edges of old forest tracks, and forestry operations. It often forms thickets in areas disturbed but spared by fires (White and Abernetty, 1996).

Alchornea also invaded the galleries of the Sudanian forests, the clearing of forests as a result of deforestation, forming a dense thicket. It is a pioneer plant in most areas that participates in the reconstitution of forest cover (Latham, 2007). It is one of the first shrubs to appear in vegetation dominated by Chromolaena odorata (L.). It is a fast-growing plant in Congo's savannah soil, where it contributes to the restoration of the biodiversity of poor lands. Localisation of Alchornea cordifolia in young forests is also widespread in riparian areas, usually marshy areas with dense thick formation where it is often identified as aquatic macrophytes (Dibong and Ndjouondo, 2014). It grows in rainforests along rivers and dominates (Olivier et al., 2012). It dominates in edaphic forests linked to hydromorphic soils and river forests. Alchornea also colonizes valley bottoms near marshes and even grows in xerophilic zones or near rocks and savannah (Latham, 2007).

\section{Multiplication, Diseases and Pests:-}

Alchornea cordifolia can be multiplied by seeds or by stem cutting. Cuttings form roots after 8 to 9 weeks in a good substrate, but seeds take 3-12 weeks to germinate if they are placed directly in moist soil (Larbi et al., 1993; MavarManga et al., 2007). These sedimentous woody species develops low plagiotropic branches that can form roots naturally when buried or in contact with the soil. This gives this plant a good capacity to regenerate through layering (Kokou et al., 2006). Alchornea cordifolia is a food of predilection for stinking Zonocerus variegatus L. Its nectar 
glands at the base of the leaves attract the ants, which protect the plant from the attacks of other insects (MavarManga et al., 2007). A study carried out in Nigeria showed that the spots of red to pink coloration observed on its leaves generally from June to November, epidemiological period, is caused by a fungus called Taphrina deformans, which affects the synthesis of chlorophyll (Adekunle et al., 2005).

\section{Alchornea cordifolia and Polluted Environment:-}

Alchornea cordifolia is a fast-growing shrub that can grow in different types of environments or places (Makumbelo et al., 2008). Mining activities have often been shown to have a significant influence on the environment. Their ecological impact often leads to the disappearance of certain native species in the region. Recolonization of these sites is done with forest regenerating species, herbaceous plants composed of grasses and legumes, and certain trees and shrubs such as Alchornea cordifolia. The later has the capacity to regenerate or modify the soil, whatever its state of degradation of the environment. Observations made in Nigeria have shown that Alchornea colonises the degraded mining and petroleum zones after a period of six months. It represents a floristic indicator of the tropical system of land used anthropised, therefore, bioindicator (Akinbiola et al., 2016).

An impact study carried out on hydrocarbon exploitation sites in the Niger Delta shows a clear dominance of Alchornea cordifolia in the woody population of degraded areas. It represents the majority species that best adapts to hydrocarbon-contaminated environments without showing signs of toxicity (Chima and Vure, 2013; Edwin-Wosu and Sunday, 2016).

\section{Chemical and Phytochemical Compositions of Alchornea cordifolia:-}

The leaves, roots and bark of the stem of A cordifolia contain terpenoids, steroidal heterosides, flavonoids (2-3\%), tannins (about 10\%), saponins, carbohydrates and alkaloids imidazopyrimidines (alchornine, alchornidin) and several guanidine alkaloids (Ogungbamila and Samuelsson, 1989; Lamikanra et al., 1990; Ajali, 2000). There was also found in the leaves a whole set of hydroxybenzoic acids: gallic acid and its ethyl ester, gentisic acid, anthranilic acid (vitamin L1) and protocatechuic acid, and also ellagic acid (yellow alizarin). A C20 homologue of vernolic acid, called alchornoic acid, was found in seed oil (Togola, 2002; Mavar-Manga et al., 2007; Osadebe et al., 2012).

\section{Alchornea cordifolia and Traditional Medicine:-}

Throughout its range, Alchornea cordifolia is commonly used as a medicinal plant to treat several diseases. All its components are used in traditional medicine (Catarino et al., 2016). It is mainly harvested in the wild. It is used either fresh or dried and can be used alone or in combination with other species, depending on the case of disease and mode of treatment. The mode of treatment may differ from one disease to another; the plant is often either macerated, decocted, infused or looted, to administer to the patient either orally, anally or vaginally, in body bath combined with vapour baths, enema and by direct application in the form of poultice (Makumbelo et al., 2008). Alchornea cordifolia is used to treat intestinal problems including gastric ulcers, amoebic dysentery, diarrhea, worms and constipation (Agyare et al., 2014). Different types of infections, in particular of the genitourinary system, are treated in traditional medicine based on Alchornea. Its infusions, which have sedative virtues, makes it possible to combat rheumatism, splenomegaly, and postpartum haemorrhages (Mavar-Manga et al., 2008; Olivier et al., 2012).

\section{Conclusion:-}

Alchornea cordifolia has all the characteristics necessary to be an agent of phytoremediation. It has good ability to grow in environments contaminated by various types of pollutants and in extreme conditions. Moreover, its large biomass production, i.e. 2 to 3 tons per hectare per year, will allow the extraction/accumulation of target MTE which it would preferentially assimilate. On the other hand, its powerful root system would participate in the exploration of a greater volume of soil, its stabilization, and the pollutants therein. 


\section{References:-}

1. Adekunle, AA., Uma, NU. and Oleah, AM. (2005): Studies on Coloured Leaf Spot Disease of Alchornea cordifolia Caused by Taphrina deformans. Plant Pathology Journal, 4(2), 150-156.

2. Adriano, DC. (1986): Introduction. In Trace elements in the terrestrial environment (pp. 1-45). Springer.

3. Adriano, DC., Wenzel, WW., Vangronsveld, J. and Bolan, NS. (2004): Role of assisted natural remediation in $\begin{array}{lllll}\text { environmental } & \text { cleanup. } & \text { Geoderma, } & \text { 121-142. }\end{array}$ https://doi.org/http://dx.doi.org/10.1016/j.geoderma.2004.01.003

4. Agyare, C., Spiegler, V., Sarkodie, H., Asase, A., Liebau, E. and Hensel, A. (2014): An ethnopharmacological survey and in vitro confirmation of the ethnopharmacological use of medicinal plants as anthelmintic remedies in the Ashanti region, in the central part of Ghana. Journal of Ethnopharmacology, 158, 255-263.

5. Ajali, U. (2000): Antibacterial activity of Alchornea cordifolia stem bark. Fitoterapia, 71(4), 436-438.

6. Akinbiola, S., Awotoye, O., Adepoju, K. \& Salami, A. (2016): Floristic indicators of tropical landuse systems: Evidence from mining areas in Southwestern Nigeria. Global Ecology and Conservation, 7, 141-147.

7. Arbonnier, M. (2002): Arbres. Arbustes et Lianes Des Zones Sèches d'Afrique de l'Ouest\% W Copyright Cirad, 574.

8. Aricia, E. and Bruno, C. (2013): Impact des éléments-traces métalliques sur les plantes et les techniques de phytoremédiation, 59-75.

9. Arora, A., Sairam, RK. and Srivastava, GC. (2002): Oxidative stress and antioxidative system in plants. Current Science, 1227-1238.

10. Aydin, D. and Coskun, OF. (2013): Comparison of edta-enhanced phytoextraction strategies with nasturtium officinale (Watercress) on an artificially arsenic contaminated water. Pakistan Journal of Botany, 45(4), 14231429. Retrieved from http://www.scopus.com/inward/record.url?eid=2-s2.084879981149\&partnerID=40\&md5=f80682bfbb65ee8d53b0b79f3a2c13a2

11. Bin, C., Xiaoru, W. and Lee, FSC. (2001): Pyrolysis coupled with atomic absorption spectrometry for the determination of mercury in Chinese medicinal materials. Analytica Chimica Acta, 447(1), 161-169.

12. Catarino, L., Havik, PJ., Indjai, B. and Romeiras, MM. (2016): Ecological data in support of an analysis of Guinea-Bissau' s medicinal flora. Data in Brief, 7, 1078-1097.

13. Chima, UD. and Vure, G. (2013): Crude-Oil-Spill-Induced Spatial Variation in Woody Species Populations of an Oil-Rich Community in Rivers State, Nigeria. Journal of Environment and Ecology, 4(2), 7.

14. Cobbett, CS. (2000): Phytochelatins and their roles in heavy metal detoxification. Plant Physiology, 123(3), $825-832$.

15. Cook, RL. and Hesterberg, D. (2013): Comparison of Trees and Grasses for Rhizoremediation of Petroleum Hydrocarbons. International Journal of Phytoremediation, 15(9), 844-860. Retrieved from http://www.scopus.com/inward/record.url?eid=2-s2.0-

84874598499\&partnerID=40\&md5=de67b9b12912158b0aa977317e77f5b5

16. Delcarte, J., Gossiaux, L. and Evlard, A. (2013): Valorisation énergétique du bois produit à des fins de phytoremédiation. Renaturation Des Berges de Cours D'eau et Phytoremédiation, 107-119.

17. Dibong, SD. and Ndjouondo, GP. (2014): Inventaire floristique et écologie des macrophytes aquatiques de la rivière Kambo à Douala (Cameroun). Journal of Applied Biosciences, 80(1), 7147-7160.

18. Edwin-Wosu, NL. and Sunday, VN. (2016): A Baseline Environmental Impact Assessment (EIA) of Proposed Sit for Thermal Desorption Unit (TDU) Waste Management Project in Rivers State, Nigeria: Floristic Composition Approach. American Journal of Bioscience and Bioengineering, 4(2), 9-25.

19. Ernst, WHO., Verkleij, JAC. and Schat, H. (1992): Metal tolerance in plants. Acta Botanica Neerlandica, 41(3), 229-248.

20. Friis, I. and Harris, T. (2013): Alchornea cordifolia (Schumach. \& Thonn.) Muell. Arg.(Euphorbiaceae), a disjunct Guineo-Congolian tree found in Ethiopia as dominant in riverine forest. Webbia, 68(2), 147-154.

21. Gheju, M. and Stelescu, I. (2013): Chelant-assisted phytoextraction and accumulation of Zn by Zea mays. Journal of Environmental Management, 128, 631-636. Retrieved from http://www.scopus.com/inward/record.url?eid=2-s2.084880364896\&partnerID=40\&md5=bc0bdfbff481a1748b94ece9d86512da

22. Ghnaya Aben, Charles, G., Hamida, JBEN. and Branchard, M. (2006): Phytoremédiation : apport de la sélection in vitro pour l'obtention de Colza ( Brassica napus L.) tolérant aux métaux toxiques . Phytoremediation : in vitro selection of Rapeseed ( Brassica napus L .) tolerant of toxic metals ., 69-86.

23. Habeck, M. (2011): Toxicological Profile for Manganese Agency for Toxic Substances and Disease Registry, United States Public Health Service.

24. Hooda, V. (2007): Phytoremediation of toxic metals from soil and waste water, 28(April), 367-376. 
25. IUCLID, F. (2000): International Uniform Chemical Information Database. European Commission ISPRA CD $R O M$.

26. Joner, EJ., Leyval, C. and Colpaert, JV. (2006): Ectomycorrhizas impede phytoremediation of polycyclic aromatic hydrocarbons (PAHs) both within and beyond the rhizosphere. Environmental Pollution, 142(1), 3438. https://doi.org/http://dx.doi.org/10.1016/j.envpol.2005.09.007

27. Kabata-Pendias, A. (2010): Trace elements in soils and plants. CRC press.

28. Kidd, P., Barceló, J., Bernal, MP., Navari-Izzo, F., Poschenrieder, C., Shilev, S. and Monterroso, C. (2009): Trace element behaviour at the root-soil interface: Implications in phytoremediation. Environmental and Experimental Botany, 67(1), 243-259. https://doi.org/http://dx.doi.org/10.1016/j.envexpbot.2009.06.013

29. Kokou, K., Atato, A., Bellefontaine, R., Kokutse, AD. and Caballé, G. (2006): Diversité des forêts denses sèches du Togo (Afrique de l'Ouest).

30. Krznaric, E., Verbruggen, N., Wevers, JHL., Carleer, R., Vangronsveld, J. and Colpaert, JV. (2009): Cd-tolerant Suillus luteus: A fungal insurance for pines exposed to Cd. Environmental Pollution, 157(5), 1581-1588. https://doi.org/http://dx.doi.org/10.1016/j.envpol.2008.12.030

31. Kushwaha, A., Rani, R., Kumar, S. and Gautam, A. (2016): Heavy metal detoxification and tolerance mechanisms in plants : Implications for phytoremediation, 51(February 2015), 39-51.

32. Lamikanra, A., Ogundaini, AO. and Ogungbamila, FO. (1990): Antibacterial constituents of Alchornea cordifolia leaves. Phytotherapy Research, 4(5), 198-200.

33. Larbi, A., Jabbar, MA., Orok, EJ., Idiong, NB. and Cobbina, J. (1993): Alchornea cordifolia, a promising indigenous browse species adapted to acid soils in southeastern Nigeria for integrated crop-livestock agroforestry production systems. Agroforestry Systems, 22(1), 33-41.

34. Latham, P. (2007): Plantes utiles du Bas-Congo, Republique Democratique du Congo. Mystole Publications. Retrieved from https://books.google.be/books?id=mmgoAQAAIAAJ

35. Lesage, E., Meers, E., Vervaeke, P., Lamsal, S., Hopgood, M., Tack, FMG. and Verloo, MG. (2005): Enhanced phytoextraction: II. Effect of EDTA and citric acid on heavy metal uptake by Helianthus annuus from a calcareous soil. International Journal of Phytoremediation, 7(2), 143-152.

36. Leteinturier, B. (2002): Evaluation du potential phytocénotique des gisements cuprifères d'Afrique centroaustrale en vue de la phytoremédiation de sites pollués par l'activité minière. Faculté Des Sciences Agronomiques de Gembloux, Gembloux.

37. Mahmood, Q., Pervez, A., Zeb, B. S., Zaffar, H., Yaqoob, H., Waseem, M., ... Afsheen. (2013): Natural treatment systems as sustainable ecotechnologies for the developing countries. BioMed Research International, 2013. Retrieved from http://www.scopus.com/inward/record.url?eid=2-s2.084880175374\&partnerID=40\&md5=719637e1529d8d669e15336b79d01737

38. Makumbelo, E., Lukoki, L., Paulus, J. and Luyindula, N. (2008): Stratégie de valorisation des espèces ressources des produits non ligneux de la savane des environs de Kinshasa: II. Enquête ethnobotanique (aspects médicinaux). Tropicultura, 26(3), 129-134.

39. Mavar-Manga, H., Haddad, M., Pieters, L., Baccelli, C., Penge, A. and Quetin-Leclercq, J. (2008): Antiinflammatory compounds from leaves and root bark of Alchornea cordifolia (Schumach. \& Thonn.) Müll. Arg. Journal of Ethnopharmacology, 115(1), 25-29.

40. Mavar-Manga, H., Lejoly, J., Quetin-Leclercq, J. and Schmelzer, GH. (2007): Alchornea cordifolia (Schumach. \& Thonn.) Müll. Arg. Prota, 11(1).

41. Miller, CS. and Gosling, WD. (2014): Quaternary forest associations in lowland tropical West Africa. Quaternary Science Reviews, 84, 7-25.

42. Moogouei, R., Borghei, M. and Arjmandi, R. (2011): Phytoremediation of stable Cs from solutions by Calendula alata, Amaranthus chlorostachys and Chenopodium album. Ecotoxicology and Environmental Safety, 74(7), 2036-2039. https://doi.org/http://dx.doi.org/10.1016/j.ecoenv.2011.07.019

43. Moon, A. (2005): Regulatory and functional interaction of plant growth regulators and plant glutathione Stransferases (GSTs). Vitam Horm. 72:155-202.

44. Ogungbamila, FO. and Samuelsson, G. (1989): Smooth muscle relaxing flavonoids from Alchornea cordifolia. Acta Pharmaceutica Nordica, 2(6), 421-422.

45. Olivier, M., Zerbo, P., Boussim, JI. and Guinko, S. (2012): Les plantes des galeries forestières à usage traditionnel par les tradipraticiens de santé et les chasseurs Dozo Sénoufo du Burkina Faso. International Journal of Biological and Chemical Sciences, 6(5), 2170-2191.

46. Osadebe, PO., Okoye, FBC., Uzor, PF., Nnamani, NR., Adiele, IE. and Obiano, NC. (2012): Phytochemical analysis, hepatoprotective and antioxidant activity of Alchornea cordifolia methanol leaf extract on carbon tetrachloride-induced hepatic damage in rats. Asian Pacific Journal of Tropical Medicine, 5(4), $289-293$. 
47. Osumah, RO. (2012): Phytochemical and antibacterial studies of the stem bark and root of Alchornea cordifolia (euphorbiaceae).PhD thesis, Ahmadu Bello University, Zaria, p. 136.

48. Pulford, ID. and Watson, C. (2003): Phytoremediation of heavy metal-contaminated land by trees-a review. Environment International, 29(4), 529-540.

49. Punshon, T. (1996): Heavy metal resistance in Salix. Liverpool John Moores University.

50. Quigley, YMK. (2005): Willows beyond wetlands: Uses of Salix L. species for environmental projects. Ecological(Engineering), 162(1-4), 183-204.

51. Raskin, I., Smith, RD. and Salt, DE. (1997): Phytoremediation of metals: using plants to remove pollutants from the environment. Current Opinion in Biotechnology, 8(2), 221-226. https://doi.org/http://dx.doi.org/10.1016/S0958-1669(97)80106-1

52. Rauser, WE. (1990): Phytochelatins. Annu Rev Biochem 59: 61-86

53. Rodríguez-Serrano, M., Romero-Puertas, MC., Pastori, GM., Corpas, FJ., Sandalio, LM., Del Río, LA. and Palma, JM. (2007): Peroxisomal membrane manganese superoxide dismutase: characterization of the isozyme from watermelon (Citrullus lanatus Schrad.) cotyledons. Journal of Experimental Botany, 58(10), $2417-2427$.

54. Sinha, S., Mishra, RK., Sinam, G., Mallick, S. and Gupta, AK. (2013): Comparative Evaluation of Metal Phytoremediation Potential of Trees, Grasses, and Flowering Plants from Tannery-Wastewater-Contaminated Soil in Relation with Physicochemical Properties. Soil and Sediment Contamination, 22(8), 958-983. Retrieved from http://www.scopus.com/inward/record.url?eid=2-s2.084879035025\&partnerID=40\&md5=97c022b78b00d26f10b6faf84c98c102

55. Smith, KA. and Paterson, JE. (1995): Manganese and cobalt. Heavy Metals in Soils, 224-244.

56. Togola, A. (2002): Étude de la phytochimie et de l'activité antipaludique d'Alchornea cordifolia Schmach. Euphorbiaceae). Doctorat d'Etat En Pharmacie, Université de Bamako, Mali.

57. Vervaeke, P., Luyssaert, S., Mertens, J., Meers, E., Tack, FMG. and Lust, N. (2003): Phytoremediation prospects of willow stands on contaminated sediment: a field trial. Environmental Pollution, 126(2), $275-282$. https://doi.org/http://dx.doi.org/10.1016/S0269-7491(03)00189-1

58. Vishnoi, SR. and Srivastava, PN. (2007): Phytoremediation-green for environmental clean. In Proceedings of Taal2007: the 12th World lake conference (Vol. 1016, p. 1021).

59. White, L. and Abernetty, K. (1996): A guide to the vegetation of the Lopé. ECOFAC GABON.

60. Wolverton, B. (1980): Phytoremédiation, 1-10.

61. Yadav, SK. (2010): Heavy metals toxicity in plants: An overview on the role of glutathione and phytochelatins in heavy metal stress tolerance of plants. South African Journal of Botany, 76(2), 167-179. https://doi.org/http://dx.doi.org/10.1016/j.sajb.2009.10.007

62. Zhang, BY., Zheng, JS. and Sharp, RG. (2010): Phytoremediation in Engineered Wetlands : Mechanisms and Applications, 2(5), 1315-1325. https://doi.org/10.1016/j.proenv.2010.10.142 